\title{
Capacity Building Evaluation: Efforts to Improve Performance in Central Java Quality Assurance Institutions
}

\author{
Nugraheni Triastuti ${ }^{1}$, Sundarso $^{2}$, Hartuti Purnaweni ${ }^{3}$, Kismartini $^{4}$ \\ \{nugrahenitriastuti@students.undip.ac.id ${ }^{1}$ \} \\ Universitas Diponegoro, Indonesia ${ }^{1,2,3,4}$
}

\begin{abstract}
This research is aimed at analyzing the efforts of improving Central Java Quality Assurance Institution's staff. The capacity building does not only focus on creating organizational performance (non-profit/profit) but also government performance. More than that, the capacity building that is carried out should be able to provide an evaluation of the achievement targets that have existed in the past and allow the capacity building to see which sides need to be strengthened, what things must be prioritized and of course in what ways the desired goals can be achieved. Capacity building that is not preceded by a comprehensive study of organizational needs and an assessment of preexisting conditions will generally only limit training. Yet according to the level of need, it must cover all organizational components. Therefore, the Central Java Education Quality Assurance Agency sees the need for an evaluation of the capacity building to control organizational performance accountability through measurement based on changes in performance based on institutional arrangements, leadership, knowledge and organizational accountability which will ultimately have an impact on organizational performance.
\end{abstract}

Keywords: Ability to Make Changes, Performance Improvement, Training

\section{Introduction}

The existence of an organization in order to run according to expectations has at least five basic assets, namely a visionary leader, a clear and specific vision and mission (objectives) of the organization, quality human resources, good organizational management and the availability of adequate financial resources. Human resources, both in terms of quality and quantity, can be seen from attitudes/behavior, expertise and knowledge. The role of capacity building in this case certainly contributes to the improvement of attitudes, skills and knowledge for the apparatus so that they are able to carry out tasks in accordance with the existing vision and mission so that organizational goals can be implemented and realized [1]. Central Java Education Quality Assurance Institute's staff members are civil service servants familiarly called ASN (Aparatur Sipil Negara). ASN are selected and employed by the government to conduct the assignments of the institution.

It must be understood that the progress or failure of an organization really depends on the existence of human resources (ASN) in moving the organization. So that capacity building for ASN is an absolute must be implemented. This can be done by means of competency-based education and training, fostering clear and measurable career patterns, learning assignments, 
and playing patterns (outbound) during educational activities so that they can have an impact when carrying out assignments. However, capacity building can be carried out if there is support or the organization has the ability, one of which is the availability and capacity of adequate funding sources.

The capacity building program carried out at the Central Java Educational Quality Assurance Institute, namely Human Resource Competency Development which was held in February-March 2018, Employee Competency Improvement Workshop held in FebruaryMarch 2019, and Capacity Building and Strategies for Improving the Quality of Human Resources for Apparatus implemented in November 2019. The purpose of this paper is to see the extent of the impact of the capacity building program carried out at the Education Quality Assurance Institute (LPMP) in Central Java.

\section{Methodology}

The method used in this paper is a qualitative approach that uses a questionnaire instrument as an aid in analyzing the results of program evaluations carried out to employees of the Central Java Education Quality Assurance Institute. The number of the informants is 160 people, that is the staf member of the Education Quality Assurance Institute (LPMP) in Central Java.

\section{Discussion}

\subsection{Program Evaluation}

Evaluation is an assessment of data collected through an assessment. The data collected can be used for the decision-making process with data that has been obtained through measurement using either test or non-test instruments. Literally evaluation comes from the word evaluation in English. The word is absorbed into the vocabulary of the Indonesian term "evaluation".

Arikunto and Jabar [2] defines that, evaluation is an activity to find something valuable about something; In searching for something, it also includes finding useful information in assessing the existence of a program, production, procedure, and proposed alternative strategies to achieve predetermined goals.

Another definition from Schuman views evaluation as a process of determining the results that have been achieved by several planned activities to support the achievement of goals [2].

Furthermore, the Joint Committee on Standards for Educational Evaluation, 1994. Stated: Evaluations means a study designed and conducted to assist some audience to assess an object's merit and worth [3].

\subsection{Capacity Building}

The view of experts regarding development Hasibuan [4], Budiarti [5] states that development is a process carried out by an organization to members of the organization/employees in order to improve technical, theoretical, conceptual and moral 
abilities and skills both with education and training within a certain period of time in accordance with needs of jobs/positions carried out by members of the organization. It is slightly different Jusuf [6] that floating does help individuals to improve and foster their abilities, attitudes and pers

Onalities to handle future responsibilities even though they are not related to the position they are taking or the future positions. Development shows changes in skills, knowledge, attitudes or behaviour. Development activities are planned organizational improvement programs and it is important that they are planned as carefully as possible because the end goal is to relate training content to the desired behaviour [7].

From some of the definitions above, it can be concluded that the main object of special concern in development is humans by increasing technical, theoretical, conceptual and moral abilities with educational and training activities within a certain period based on systematic and organized procedures to be able to carry out tasks and responsibilities both now and in the future.

Competence can be defined as an individual's ability to show his work according to the required standards [8]. The main focus of competence is the capacity or behaviour that an employee/staff brings into their position to carry out their duties and functions effectively. In this connection, it is necessary to establish competency standards that are intended so that the apparatus resources (SDA) have clear references, Lely and Signe [9] there are five (5) types of competency characteristics, namely: motive, traits, and self-concept. -concept), knowledge (knowledge) and skills (skills). In other words, every apparatus both government and private should have competencies that refer to existing standards so that each individual in the organization is able to contribute to the achievement of organizational goals. including:

The competency acquisition process has been developed to improve competence [10]

1) Recognition is a simulation that provides an opportunity for participants to recognize one or more competencies that can predict high-working individuals in their work so that someone can walk from the simulation experience.

2) Understanding is a special instruction including a model of behaviour about what competencies are and how they are applied.

3) Assessment is feedback to participants about how many competencies the participants have (comparing participants' scores). With this, it is able to motivate participants to learn competencies, so that they are aware of the relationship between actual performance and ideal performance.

4) Feedback is an exercise in which participants can practice their competencies and get feedback on how participants can carry out certain jobs compared to someone with high performance.

5) Job Application is the application of competence in real life.

Capacity building is a concept that developed quite rapidly in the early 19th century, especially for academic studies which at that time experienced various deteriorations, especially in government administration such as organizational inefficiency and ineffectiveness. The capacity building program provides good hope, especially in the context of realizing the goal of effective and efficient public management of government to realize organizational goals in accordance with the expected vision and mission.

The capacity building program for local government in Indonesia at that time was specifically designed to increase the capacity of district/city governments Haryono et.al., [11] to be able to: 1. Manage government activities, 2. Encourage public participation, 3. 
Encourage the growth of private sectors, and 4. Developing cooperation networks with outside parties.

Capacity building is a series of strategies aimed at increasing the efficiency, effectiveness and responsiveness of government performance which is focused on the following dimensions: 1) Human resource development, 2) Organizational strengthening, and 3) Institutional reform [12]. All of the above capacity building dimensions are developed as a strategy to realize the values of "good governance" [13]. Human resource development, for example, can be seen as a strategy to increase efficiency and effectiveness as well as maintain moral values and work ethic.

Many authors who refer to "capacity building" do so in broad terms that do not distinguish the organizational capacity building from the capacity building at the individual, community, or institutional level [14]. Capacity building as any type of action or process that increases the ability to carry out activities or functions [15][16][17]. Refers to the process by which individuals, organizations, institutions and communities develop the ability (individually and collectively) to perform functions, solve problems and set and achieve goals, development work that strengthens the ability of communities and groups to build their capacities [18][1]. Capacity building can provide practical responses; as an instrument that builds organizational capacity and protects organizational autonomy [19].

\subsection{Capacity Building for ASN Increasing the Capacity of Education Quality Assurance Institutions in Central Java}

Almost all references related to capacity building Grindle [12], Brown and Lissane [20], Light [21], Rosalyn [22], Haryono et al. [11] aim of building capacity is to create organizational performance (non-profit / profit), especially effective and efficient government performance which is sustainable in nature. As expressed in the theme in this paper, that capacity building will create/improve government performance.

Currently, the performance of many government agencies is under the spotlight. This is a demand from the existing democratic climate and broad information disclosure so that everyone can be an instrument of evaluator for government performance. The public begins to be critical when they receive unfavourable treatment or service from the government and openness to complaints from this attitude to institutions appointed by the government to handle the problems faced, such as the ombudsman. Even though the routine and development budgets issued by the government are getting bigger, this is not an indicator for public satisfaction with government performance. In addition, measuring the success and failure of government agencies in carrying out their main duties and functions is difficult to carry out objectively. This difficulty is due to the fact that measuring the performance of a government agency places more emphasis on the ability to absorb the budget even though the results and impacts achieved from the implementation of the program are still far from being expected. Therefore, we need a performance measurement system that is able to provide information on the effectiveness and efficiency of an organization's performance achievement.

Performance measurement is a management instrument used to improve the quality of decision making and accountability [23]. Performance measurement can also be used to assess the achievement of goals and objectives. There are key elements of a performance measurement system [23] which consists of:

1) Planning and goal setting;

2) Development of relevant measures;

3) Formal reporting and results; and 
4) Use of information.

Capacity Building, of course, is not only oriented to human capabilities but includes the entire scope of the organization which consists of an organizational structuring system or what is known as a management system, target policies, achievement strategies and organizational regulations [24]. Such scope indicates that there is a level of capacity development from capacity development or capacity strengthening, which means developing existing capacities and developing capacities that prioritize creative processes to build capacities that have not yet been seen.

In the end, capacity development will also provide an evaluation of the achievement targets that have existed in the past and allow the capacity building to see which sides need strengthening, which things must be prioritized and of course in what ways the achievement of the desired goals can be achieved. Therefore, the capacity building that does not begin with a comprehensive study of organizational needs and an assessment of pre-existing conditions will generally only be limited to training. Whereas according to the level of development, it must cover all organizational components. There is a need for capacity building evaluation to control the accountability of organizational performance through measurement based on changes in performance based on institutional arrangements, leadership, knowledge and organizational accountability which will ultimately have an impact on the performance of an organization.

The explanation above shows how important it is for an organization to develop capacity which should be carried out in a comprehensive study of the organization so that the focus on improving performance can be done and the accuracy in making decisions about what will be developed for the progress of the organization will be clear and directed. There is a positive and significant influence on human resource development, organizational strengthening and institutional reform on organizational performance [25].

\subsubsection{Evaluation Results of Activity Programs in February-March 2018}

1. Program suitability, participants assessed the implementation of the activity program as appropriate, which was indicated by the average score of participants' answers of 3.2. Participants who considered very appropriate were $30.68 \%, 61.93 \%$ appropriate, $7.39 \%$ sufficient, $0 \%$ less, and $0 \%$ not answering.

2. Supporting Facilities Readiness, participants assess that the supporting facilities provided are ready. This is indicated by the average score of participants' answers of 3.2. Participants who considered very ready were $28.41 \%, 67.05 \%$ ready, $4.55 \%$ sufficient, $0 \%$ lacking, and $0 \%$ not answering.

3. Material Benefits, participants rated the material provided Useful, which was indicated by the average score of participants' answers of 2.8. Participants who considered very useful were $22.73 \%, 61.36 \%$ useful, $6.82 \%$ sufficient, less than $0 \%$, and those who did not answer were $9.09 \%$.

4. Participants 'evaluation of program activities carried out by sampling, it can be concluded that the Central Java LPMP Human Resource Competency Development Capacity Building activities are appropriate, ready and useful, which is shown by the average score of participants' answers of 3.1. 


\subsubsection{Evaluation Results of Activity Programs in February-March 2019}

1. Program suitability, participants assess that the implementation of the activity program is appropriate, which is indicated by the average score of participants' answers of 3.3 . Participants who considered very appropriate were $35.96 \%, 57.46 \%$ suitable, $6.14 \%$ sufficient, $0 \%$ less, and $0.44 \%$ did not answer.

2. Supporting Facilities Readiness, participants assess that the supporting facilities provided are ready. This is indicated by the average score of participants' answers of 3.3 . Participants who rated very ready were $32.46 \%, 63.16 \%$ ready, $4.39 \%$ sufficient, $0 \%$ less, and $0 \%$ not answering.

3. Material Benefits, participants rated the material provided Useful, which was indicated by the average score of participants' answers of 3.1. Participants who considered very useful were $29.39 \%, 59.65 \%$ useful, $5.26 \%$ sufficient, $0 \%$ less, and $5.70 \%$ who did not answer.

4. The results of the participant evaluation of the program activities carried out by sampling, it can be concluded that the Workshop for Employee Competency Improvement is appropriate, ready and useful, as indicated by the average score of participants' answers of 3.2 .

\subsubsection{Evaluation Results of Activity Programs in November 2019}

1. Program suitability, participants assessed that the implementation of the activity program was very appropriate, as indicated by the average score of participants' answers of 4.57 . Participants who rated very appropriate was $63.21 \%, 31.07 \%$ appropriate, $5.36 \%$ quite appropriate, $0.36 \%$ less appropriate, $0 \%$ very inappropriate, and $0 \%$ not answering.

2. The readiness of Supporting Facilities, participants considered that the supporting facilities provided were very ready. This is indicated by the average score of participants' answers of 4.62 . Participants who rated very ready were $67.86 \%, 26.43 \%$ ready, $5.71 \%$ quite ready, $0 \%$ less ready, $0 \%$ much unprepared and $0 \%$ not answered.

3. Material Benefits, participants rated the material provided as very useful, which was indicated by the average score of participants' answers of 4.57. Participants who rated very useful were $62.14 \%, 33.57 \%$ useful, $3.57 \%$ quite useful, $0.71 \%$ less useful, $0 \%$ very less useful, and those who did not answer were $0 \%$.

The results of the participant evaluation of the program of activities carried out by sampling, it can be concluded that the Capacity Building activities and the Strategy for Improving the Quality of Human Resources for Apparatus are very appropriate, very ready and very useful, which is shown by the average score of participants' answers of 4.58 .

\section{Conclusion}

The results of the evaluation carried out in the capacity building program at LPMP Central Java can be concluded:

1. Analysis of the results of the participant's assessment based on the assessment instrument for the implementation of the Employee Competency Improvement Workshop shows that the majority of the participants considered the activities carried out as GOOD and SATISFACTORY. 
2. Analysis of the results of participant assessments based on the assessment instrument for the implementation of the Workshop for Employee Competency Improvement the 2019 Workshop for Employee Competency Improvement shows that the majority of participants rated the activities carried out as GOOD and SATISFACTORY of participants.

3. An analysis of the results of the participant's assessment based on the assessment instrument for the implementation of Capacity Building activities and the Strategy for Improving the Quality of Human Resources for Apparatus indicates that the majority of participants considered that the activities carried out were GOOD and SATISFACTORY.

\section{References}

[1] S. Skinner, "Building Community Strengths: A resource book on capacity building," 1997.

[2] S. Arikunto and C. S. A. Jabar, "Evaluasi Program Pendidikan, Cet," V, Jakarta Bumi Aksara, 2014.

[3] G. Rogers and L. Badham, Evaluation in Schools: Getting Started with Training and Implementation. Routledge, 2003.

[4] M. S. P. Hasibuan, "Manajemen sumber daya manusia edisi revisi," Bumi Aksara, Jakarta, vol. 288, 2005.

[5] I. Budiarti, "Manajemen sumber daya manusia," 2010

[6] J. Irianto, "Prinsip-prinsip dasar manajemen pelatihan," Surabaya Insa. Cendekia, 2001.

[7] S. Henry, "Manajemen Sumber Daya Manusia, Edisi ke 1, STIE YKPN.” Yogyakarta, 2005.

[8] A. Mongilong, F. Singkoh, and J. Kairupan, "Pengembangan Kapasitas Aparatur Sipil Negara dalam Meningkatkan Profesionalisme Kerja di Badan Pengelola Keuangan dan Aset Daerah Kabupaten Bolaang Mongondow," J. Eksek., vol. 1, no. 1, 2018.

[9] M. L. Spencer and M. S. Spencer, "Competence at Work: Models for Superrior Performance, John Wily and Son," Inc. New York, USA, 1993.

[10] D. HIRMA, "Manajemen kinerja," 2005.

[11] B. S. Haryono, S. Zauhar, and B. Supriyono, Capacity Building. Universitas Brawijaya Press, 2012.

[12] M. S. Grindle, Getting good government: capacity building in the public sectors of developing countries. Harvard Univ Pr, 1997.

[13] R. Soeprapto, "Pengembangan Kapasitas Pemerintah Daerah Menuju Good Governance," J. Ilm. Adm. Publik FIA Univ. Brawijaya, Nomor, vol. 4, p. 2003, 2003.

[14] S. Banks and F. Shenton, "Regenerating neighbourhoods: a critical look at the role of community capacity building," Local Econ., vol. 16, no. 4, pp. 286-298, 2001.

[15] M. Gibbon, R. Labonte, and G. Laverack, "Evaluating community capacity," Health Soc. Care Community, vol. 10, no. 6, pp. 485-491, 2002.

[16] H. R. Yeatman and T. Nove, "Reorienting health services with capacity building: a case study of the Core Skills in Health Promotion Project," Health Promot. Int., vol. 17, no. 4, pp. 341$350,2002$.

[17] M. Murray and L. Dunn, "Capacity building for rural development in the United States," $J$. Rural Stud., vol. 11, no. 1, pp. 89-97, 1995.

[18] J. Twigg, "Capacity Building and its Challenges: A review of the Baring Foundation's International Grants Programme 1997-1999," Baring Found. London, 2001.

[19] B. Cairns, M. Harris, and P. Young, "Building the capacity of the voluntary nonprofit sector: Challenges of theory and practice," Intl J. Public Adm., vol. 28, no. 9-10, pp. 869-885, 2005.

[20] L. Brown, A. LaFond, and K. Macintyre, "Measuring capacity building California Population Center," Univ. North Carolina Chapel Hill Retrieved from http//www. cpc. unc. edu/measure/resources/publications/sr-01-05/at_download/document, 2001.

[21] P. C. Light, Sustaining nonprofit performance: The case for capacity building and the evidence 
to support it. Brookings Institution Press, 2004.

[22] R. Rubenstein, Capacity building as a model for arts, heritage and cultural leadership, Principal of Rubenstein \& Associates. 2008.

[23] J. B. Whittaker, "The Government Performance and Result Act of 1993; 1995," A mandate Strateg. Plan. Perform. Meas. Educ. Serv. Institute, Arlington, Virginia, USA, 1995.

[24] A. E. Wibawa, "Capacity Building dan Strategi Peningkatan Kualitas SDM Organisasi," 2014. .

[25] S. R. Arfah, "PENGARUH CAPACITY BUILDING TERHADAP KINERJA SKPD PEMERINTAH KOTA MAKASSAR,” J. Adm. Negara, vol. 24, no. 2, pp. 115-126, 2018. 